\title{
Nematode parasites of two anuran species Rhinella schneideri (Bufonidae) and Scinax acuminatus (Hylidae) from Corrientes, Argentina
}

\author{
Cynthya Elizabeth González ${ }^{1} \&$ Monika Inés Hamann ${ }^{2}$ \\ 1,2. Centro de Ecología aplicada del Litoral (CECOAL), Consejo Nacional de Investigaciones Científicas y Técnicas \\ (CONICET), C.C. 291, C.P. 3400, Corrientes, Argentina; \\ 1. cynthyaelizabethg@hotmail.com; \\ 2. monika_hamann@yahoo.com
}

Received 10-I-2008. C Corrected 30-VI-2008. Accepted 31-VII-2008.

\begin{abstract}
The nematological fauna of most anuran species from Corrientes province, north of Argentina; has not been studied. We report for the first time the nematode species found in Rhinella schneideri and Scinax acuminatus. Forty four amphibians representing two species (R. schneideri -six males, three females and two juveniles- and $S$. acuminatus -fifteen males and eighteen females) were collected near the city of Corrientes, between January 2002 and December 2003 and searched for nematodes. $R$. schneideri contained eight species of nematodes (adults: Rhabdias füelleborni, R. elegans, Oswaldocruzia proencai, Cosmocerca podicipinus, $C$. parva and Falcaustra mascula; larvae: Porrocaecum sp. and Physaloptera sp.), and S. acuminatus contained three (adults: Cosmocerca parva and Oxyascaris caudacutus; larvae: Physaloptera sp.). We present morphology (scanning electron microscope) and metric information, range extensions, and new host records for these nematode species. Rev. Biol. Trop. 56 (4): 2147-2161. Epub 2008 December 12.
\end{abstract}

Key words: Amphibians, Rhinella schneideri, Scinax acuminatus, Nematodes, Corrientes, Argentina.

Lavilla et al. (2000) referred to 52 species of anurans for Corrientes province in the north of Argentina; the nematological fauna of most to these species has not been studied. Mordeglia and Digiani (1998) and González and Hamann (2004, 2006a, b, 2007a,b,c) have analyzed nematode parasites of the following species: Chaunus granulosus major (Müller \& Hellmich, 1936), C. fernandezae (Gallardo, 1957), C. bergi (Céspedez, 2000) (Bufonidae), Lysapsus limellum Cope, 1862 (Hylidae), Pseudopaludicola falcipes (Hensel, 1867) (Leiuperidae), and, Leptodactylus bufonius Boulenger, 1894 (Leptodactylidae). Nematodes of larval amphibians have been reported by González and Hamann (2005) who found one pharyngodonid species, Gyrinicola chabaudi Araujo \& Artigas, 1982 in tadpoles of the hylid Scinax nasicus (Cope, 1862).
Continuing the study of Argentinean amphibians, we analyzed the parasite fauna of one bufonid species, Rhinella schneideri (Werner, 1894), and one hylid species, Scinax acuminatus (Cope, 1862).

Rhinella schneideri is distributed from the Atlantic coast of Brazil inland through Paraguay to central Bolivia; and southwest to northern and central Argentina and Uruguay, whereas to $S$. acuminatus is distributed in southern Mato Grosso and Mato Grosso do Sul (Brazil), Paraguay, Bolivia and northern Argentina (Frost 2007). Rhinella schneideri, like the majority species of Rhinella, is highly terrestrial and is an active predator with a generalist diet. On the other hand, S. acuminatus occurs in forests, shrublands, and grasslands, and is very well adapted to anthropogenic areas; it has a generalist diet that it can be 
considered intermediate between a sit-and-wait and an actively foraging predator (Duré 2004).

The purpose of this study is to report for the first time nematodes harboured by $R$. schneideri and $S$. acuminatus. We describe the nematodes found in both species and present new morphological and metric data.

\section{MATERIAL AND METHODS}

Samples of $R$. schneideri $(\mathrm{N}=11)$ and $S$. acuminatus $(\mathrm{N}=33)$ were collected near the city of Corrientes, Province of Corrientes in Argentina $\left(27^{\circ} 28^{\prime} \mathrm{S}-58^{\circ} 50^{\prime} \mathrm{W}\right)$, between January 2002 and December 2003. Six males (snout-vent length - SVL) $=42.58 \mathrm{~mm} \pm 31.82$ $\mathrm{SD}$; $\min .-\max .=10.1-86.6$ and $26.0 \mathrm{~g} \pm 37.0$ $\mathrm{SD}$; min. $-\max .=0.19-86.6$ of weight), three females $(\mathrm{SVL}=81.8 \mathrm{~mm} \pm 77.8 \mathrm{SD}$; min. - max. $=23.0-170.0$, and $23.4 \mathrm{~g} \pm 24.5 \mathrm{SD}$; min. - max. $=1.8-50.0$ of weight), and two juvenile (SVL $=15.75 \mathrm{~mm} \pm 1.06 \mathrm{SD}$; $\min .-\max .=15.0-16.5$ and $0.39 \mathrm{~g} \pm 0.007 \mathrm{SD}$; min. $-\max .=0.39-0.4$ of weight), of $R$. schneideri were collected. Fifteen males (snout-vent length - SVL) = $33.64 \mathrm{~mm} \pm 5.42 \mathrm{SD}$; $\min .-\max .=25.5-43.0$ and $3.87 \mathrm{~g} \pm 1.48 \mathrm{SD}$; min. $-\max .=1.24-6.29$ of weight) and eighteen females (snout-vent length - SVL) $=29.44 \mathrm{~mm} \pm 4.65 \mathrm{SD}$; min.$\max .=21.0-41.0$ and $3.06 \mathrm{~g} \pm 1.99 \mathrm{SD}$; min.max. $=0.74-9.19$ of weight) of $S$. acuminatus were collected in same area.

Amphibians were transported live to the laboratory, killed in a chloroform $\left(\mathrm{CHCL}_{3}\right)$ solution; and their snout-vent length (SVL) and body weight were recorded. At necropsy, hosts were sexed and the alimentary canal, lungs, liver, kidneys, urinary bladder, musculature and integument examined for parasites by dissection. Nematodes were observed in vivo, counted and killed in hot distilled water and preserved in $70 \%$ ethyl alcohol, cleared in glycerine or lactophenol and examined as temporary mounts. Some specimens were studied by scanning electron microscopy (SEM); these specimens were dehydrated in ethanol series, dried using the critical point technique, coated with gold, and examined with a JSM-5800 scanning electron microscope. Measurements are given in micrometers $(\mu \mathrm{m})$ unless otherwise stated, as the mean \pm SD followed by range in parentheses. Prevalence, mean intensity and mean abundance were calculated according to Bush et al. (1997). Voucher specimens of all nematode species were deposited in the Helminthological Collection of the Centro de Ecología Aplicada del Litoral (CECOAL), Corrientes, Argentina. Amphibians were deposited in the Herpetological Collection of CECOAL ( $S$. acuminatus: Cecoal 2405; $R$. schneideri: Cecoal 2663)

\section{RESULTS}

A total of 153 nematodes was collected from 44 anurans examined. In $R$. schneideri, we found eight species of nematodes from six families: Rhabdiasidae: Rhabdias füelleborni Travassos, 1926 and Rhabdias elegans Gutierrez, 1945; Molineidae: Oswaldocruzia proencai Ben Slimane \& Durette-Desset, 1995; Cosmocercidae: Cosmocerca podicipinus Baker \& Vaucher, 1984 and Cosmocerca parva Travassos, 1925; Kathlaniidae: Falcaustra mascula (Rudolphi, 1819) Freitas \& Lent, 1941; Ascarididae: Porrocaecum sp. (Larvae) and Physalopteridae: Physaloptera sp. (Larvae). In $S$. acuminatus, we found three species of nematodes from two families: Cosmocercidae: Cosmocerca parva and Oxyascaris caudacutus (Freitas, 1958) Baker \& Vaucher, 1984, and, Physalopteridae: Physaloptera sp. (Larvae). Prevalence, number of parasites, mean intensity, mean abundance and site of infection for each one of these nematodes in each host appear in Table 1.

Family Rhabdiasidae Railliet, 1915

Genus Rhabdias Stiles \& Hassall, 1905

Rhabdias füelleborni Travassos, 1926

(Fig. 1A)

Description: Based on 14 gravid specimens. Body of parthenogenetic female $10.18 \pm 1.12 \mathrm{~mm}(8.55-12.0 \mathrm{~mm}) \times 408.2 \pm 33.7$ (350-450). Outer layers of body cuticle inflated. 
TABLE 1

Percentage occurrence, quantity, mean intensity ( $\pm S D$ ), mean abundance $( \pm S D)$, and site of infection with nematode parasites in Rhinella schneideri and Scinax acuminatus in Corrientes, Argentina

\begin{tabular}{|c|c|c|c|c|c|}
\hline Nematodes & $\%$ & \# & $\begin{array}{c}\text { Mean } \\
\text { intensity }\end{array}$ & $\begin{array}{c}\text { Mean } \\
\text { abundance }\end{array}$ & $\begin{array}{c}\text { Site of } \\
\text { infection }\end{array}$ \\
\hline \multicolumn{6}{|l|}{ Rhinella schneideri } \\
\hline R. füelleborni Cecoal 03091901 & 9 & 76 & $38.5 \pm 53.0$ & $7.0 \pm 22.9$ & Lungs \\
\hline R. elegans Cecoal 02111301 & 9 & 1 & - & $0.09 \pm 0.3$ & Lungs \\
\hline O. proencai Cecoal 03091901 & 9 & 1 & - & $0.09 \pm 0.3$ & Small intestine \\
\hline C. parva Cecoal 02042627 & 18 & 42 & $21.0 \pm 28.28$ & $3.8 \pm 12.3$ & Large intestine \\
\hline C. podicipinus Cecoal 02123280 & 18 & 5 & $2.5 \pm 0.70$ & $0.45 \pm 1.03$ & Lungs and large intestine \\
\hline F. mascula Cecoal 02052663 & 9 & 2 & - & $0.18 \pm 0.6$ & Large intestine \\
\hline Porrocaecum sp. Cecoal 03091901 & 9 & 1 & - & $0.09 \pm 0.3$ & Liver \\
\hline Physaloptera sp. Cecoal 03013425 & 9 & 1 & - & $0.09 \pm 0.3$ & Gastric mucosa \\
\hline \multicolumn{6}{|l|}{ Scinax acuminatus } \\
\hline C. parva Cecoal 04050462 & 12 & 5 & $1.25 \pm 0.5$ & $0.15 \pm 0.44$ & Large intestine \\
\hline O. caudacutus Cecoal 03061205 & 12 & 10 & $2.5 \pm 1.29$ & $0.3 \pm 0.91$ & Large intestine and small intestine \\
\hline Physaloptera sp. Cecoal 05040701 & 3 & 9 & - & $0.03 \pm 0.17$ & Gastric mucosa \\
\hline
\end{tabular}

Oral opening small, almost circular, surrounded by six small lips. Intestine filled with brown or black contents. Clavicular esophagus $560.7 \pm 66.5(460-650) \times 63.1 \pm 7.5(50-75)$. Nerve ring 237.4 \pm 46.1 (186-350) from anterior extremity. Vulva $4.88 \pm 0.32 \mathrm{~mm}(4.42-$ $5.46 \mathrm{~mm}$ ) from anterior end of body; ovaries straight, lying along intestine. Uteri wide, filled with numerous eggs; egg shell thin, smooth, hyaline; larvate eggs placed near to the vagina $114.6 \pm 19.6(97-160) \times 58.0 \pm 9.3(48-80)$ wide. Tail conical, $358.3 \pm 69.7$ (250-450) in length.

Remarks: Rhabdias Stiles and Hassall, 1905 is a genus of nematode parasites widely distributed in ranids and bufonids but is infrequently found in salamanders, snakes and lizards (Baker 1987, Bursey et al. 2003, MartínezSalazar and León-Règagnon 2006). In South American Rhabdias füelleborni was found in Brazil, Uruguay and Paraguay in the following hosts: Bufo marinus, B. arenarum, B. ictericus, B. paracnemis (Bufonidae) and Leptodactylus pentadactylus and Eleutherodactylus guentheri
(Leptodactylidae) (Travassos 1926, Fahel 1952, Kloss 1971, 1974, Masi Pallares and Maciel 1974, Rodrigues et al. 1982, Vicente et al. 1990, Luque et al. 2005, Martins and Fabio 2005). This is the first report of $R$. füelleborni in an amphibian from Argentina. The metric and morphologic data of specimens studied here agree with those of Travassos (1926).

\section{Rhabdias elegans Gutierrez, 1945}

Description: Based on 1 gravid specimen. Body of parthenogenetic female $6.2 \mathrm{~mm}$ x $400 \mathrm{~mm}$. Cuticle swollen, with irregular folds. Head end rounded. Simple mouth, not surrounded by distinguishable lips. Esophagus, $390 \times 50$. Vulva $3.5 \mathrm{~mm}$ from anterior end of body. Uteri with numerous eggs; larvated eggs 88 x 53 wide. Tail conical 220 in length.

Remarks: In Argentina, this species was found in B. arenarum (Bufonidae) from the province of Buenos Aires (Gutierrez 1945) and from the province of Salta (Sueldo and Ramírez 1976), 

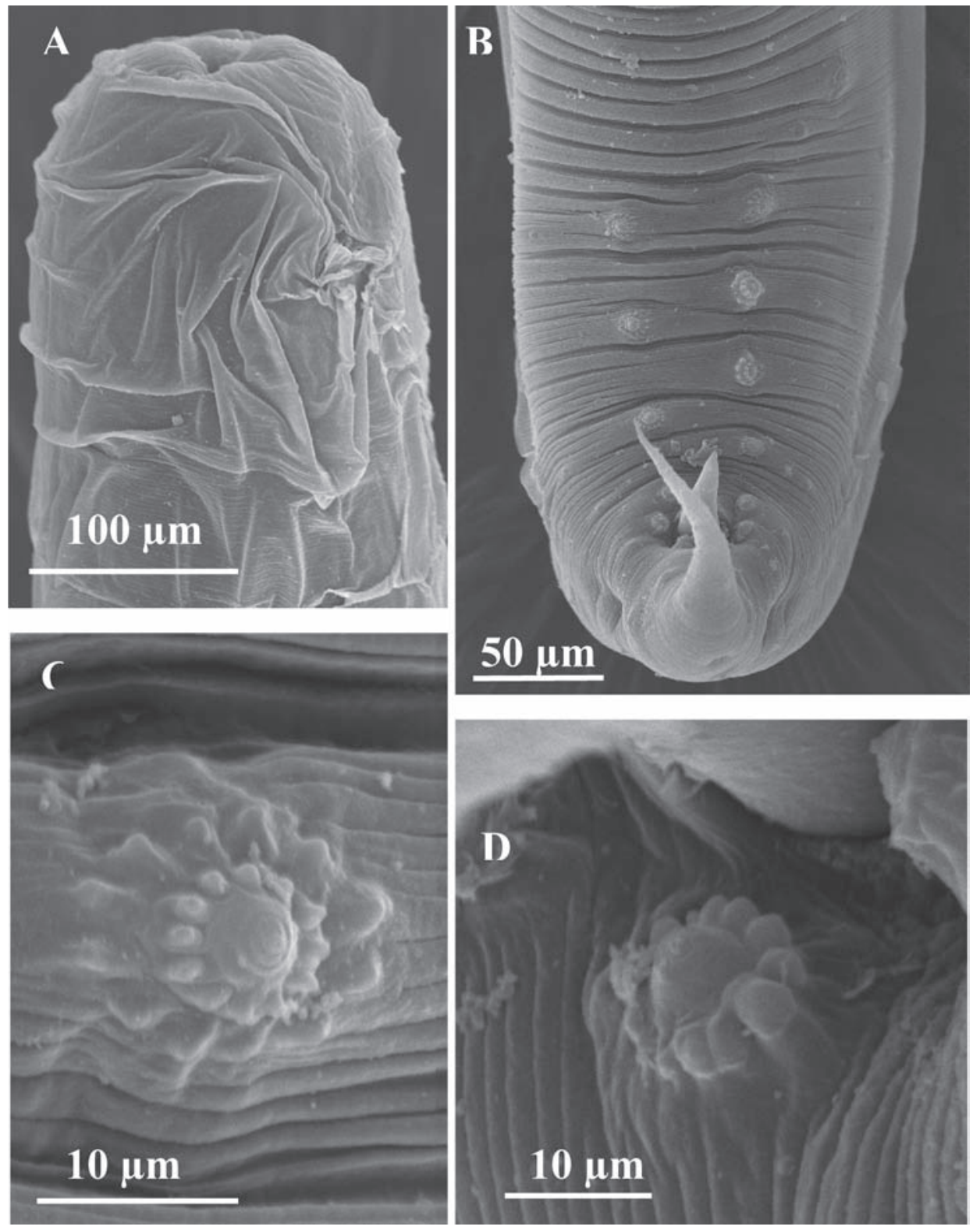

Fig. 1. Nematode parasites of Rhinella schneideri and Scinax acuminatus from Corrientes, Argentina. A. Rhabdias füelleborni, body anterior end. B. Cosmocerca parva, male, body posterior end, ventral view. C. detail of plectane. D. detail of adanal papillae, ventro-lateral view. (A-D collected from $R$. schneideri). 
in Leptodactylus bufonius (Leptodactylidae) from the province of Corrientes (González and Hamann 2006b), in Bufo rufus from Brazil, in $B$. ictericus from Paraguay and Brazil, and in B. arenarum (Bufonidae) from Uruguay (Kloss 1971, 1974, Baker 1987, Vicente et al. 1990, Luque et al. 2005).

Compared with specimens studied by Gutierrez (1945) the female found in $R$. schneideri has eggs with a smaller length (Gutiérrez 1945: 91-112 $\mu \mathrm{m}$ ); other characters (e.g., body size and esophagus length) are similar.

Family Molineidae

Durette-Desset \& Chabaud, 1977

Genus Oswaldocruzia Travassos, 1917

Oswaldocruzia proencai

Ben Slimane \& Durette-Desset, 1995

Description: Based on 1 male specimen. Body $10.5 \mathrm{~mm} \times 127.5$, with maximum width at level of midbody. Claviform esophagus 540 length. Nerve ring 184 from anterior extremity. Excretory pore 282 from anterior extremity. Caudal bursa: rays 8 arising on root of the dorsal ray, and overlapped with rays 6 in half of its length only. Dorsal ray conical, rising from common base with ribs 8 , tapering to pointed tip. Spicules 165.6 in length, distal third divided into 3 branches: blade, shoe and fork. Ribs 4 more short than ribs 5. Branches of the spicule with equivalent length.

Remarks: Ben Slimane et al. (1996) analyzed the morphology of the caudal bursa and identified 72 species of Oswaldocruzia. The species $O$. proencai is included within the groupe possessing type II bursa. The neotropical Oswaldocruzia have spicula divided in three main branches: blade, shoe and fork and the division of the fork always occurs before the distal third of its length (in holartic species occurs beyond the distal third). Gubernaculum is absent. On the other hand, Ben Slimane and Durette-Desset (1995) proposed the species $O$. proencai for the specimens collected in the amphibians Bufo paracnemis, Leptodactylus ocellatus and L. bufonius from Paraguay and that was described by Lent et al. (1946) like O. mazzai Travassos, 1935. This is the first report of $O$. proencai in an amphibian from Argentina.

\section{Family Cosmocercidae Travassos, 1925 Genus Cosmocerca Diesing, 1861 \\ Cosmocerca podicipinus \\ Baker \& Vaucher, 1984}

The caudal portion of the males of this species was extensively detailed for González and Hamann (2004), those that provided new morphologic information related to the structure of the plectanas and the adanal papillae. This species is readily distinguished from other species by the fusion of the underlying sclerotized plectane supports between the plectanes (Baker and Vaucher 1984). The Table 2 shows the metric characters of the males and females of $C$. podicipinus found in $R$. schneideri.

\section{Cosmocerca parva \\ Travassos, 1925 (Fig. 1B, C, D)}

This species is distinguished from the Cosmocerca podicipinus in the morphology of the plectanes; in $C$. parva union between the plectanas of each row does not exist, whereas in C. podicipinus the plectanes on each side of body are fused by underlying sclerotized supports; in addition, the lateral alae in this species are very marked.

The metric characters of the males and females of these nematodes found in $R$. schneideri and S. acuminatus are present in Table 2.

Remarks: In South America, the genus Cosmocerca is widely distributed in amphibians and reptiles (Baker 1987).

In Paraguay, C. podicipinus was found in Leptodactylus podicipinus, L. fuscus, L. elenae and L. chaquensis (Leptodactylidae) (Baker and Vaucher 1984); in Colombia was found by Goldberg and Bursey (2003) in Atelopus spurrelli (Bufonidae) and Dendrobates histrionicus (Dendrobatidae); in Peru was found in Bufo typhonius (Bufonidae), Colostethus 
TABLE 2

Morphology characteristics of males and females of Cosmocerca parva and C. podicipinus in Rhinella schneideri and Scinax acuminatus in Corrientes, Argentina

\begin{tabular}{|c|c|c|c|c|c|c|}
\hline & \multicolumn{2}{|c|}{$\begin{array}{l}\text { R. schneideri } \\
\text { C. podicipinus }\end{array}$} & \multicolumn{2}{|c|}{$\begin{array}{l}\text { R. schneideri } \\
\text { C. parva }\end{array}$} & \multicolumn{2}{|c|}{$\begin{array}{l}\text { S. acuminatus } \\
\text { C. parva }\end{array}$} \\
\hline & $\begin{array}{c}\text { Males } \\
\mathrm{n}=2\end{array}$ & $\begin{array}{c}\text { Females } \\
n=3\end{array}$ & $\begin{array}{c}\text { Males } \\
\mathrm{n}=5\end{array}$ & $\begin{array}{c}\text { Females } \\
n=10\end{array}$ & $\begin{array}{c}\text { Males } \\
\mathrm{n}=1\end{array}$ & $\begin{array}{c}\text { Females } \\
n=4\end{array}$ \\
\hline Total length & $\begin{array}{c}2.33 \pm 0.01 \mathrm{~mm} \\
(2.32-2.34)\end{array}$ & $\begin{array}{c}4.80 \pm 0.22 \mathrm{~mm} \\
(3.29-7.35)\end{array}$ & $\begin{array}{l}2.02 \pm 0.35 \mathrm{~mm} \\
(1.7-2.53)\end{array}$ & $\begin{array}{l}5.11 \pm 1.0 \mathrm{~mm} \\
(4.27-8.08)\end{array}$ & $2.37 \mathrm{~mm}$ & $\begin{array}{c}5.12 \pm 0.15 \mathrm{~mm} \\
(3.22-6.66)\end{array}$ \\
\hline Width & $\begin{array}{l}235.0 \pm 7.0 \\
(230-240)\end{array}$ & $\begin{array}{l}240.0 \pm 55.6 \\
(190-300)\end{array}$ & $\begin{array}{l}235.0 \pm 27.9 \\
(200-260)\end{array}$ & $\begin{array}{c}317.4 \pm 46.4 \\
(270-440)\end{array}$ & 190.0 & $\begin{array}{c}282.0 \pm 33.6 \\
(240-312)\end{array}$ \\
\hline Length of pharynx & $\begin{array}{l}26.3 \pm 1.8 \\
(25-27)\end{array}$ & $\begin{array}{l}34.5 \pm 4.5 \\
(30-39)\end{array}$ & $\begin{array}{l}27.9 \pm 2.9 \\
(23-30)\end{array}$ & $\begin{array}{c}41.0 \pm 6.1 \\
(34-49)\end{array}$ & 29.9 & $\begin{array}{l}37.1 \pm 3.8 \\
(32-41)\end{array}$ \\
\hline Width of pharynx & $\begin{array}{l}20.3 \pm 0.5 \\
(20-21)\end{array}$ & $\begin{array}{l}37.6 \pm 6.9 \\
(30-44)\end{array}$ & $\begin{array}{c}20.2 \pm 1.6 \\
(19-23)\end{array}$ & $\begin{array}{c}42.2 \pm 5.3 \\
(37-55)\end{array}$ & 18.4 & $\begin{array}{l}38.6 \pm 5.1 \\
(34-46)\end{array}$ \\
\hline $\begin{array}{l}\text { Length of muscular } \\
\text { esophagus }\end{array}$ & $\begin{array}{l}205.2 \pm 13.7 \\
(195-215)\end{array}$ & $\begin{array}{c}328.6 \pm 71.0 \\
(282-410)\end{array}$ & $\begin{array}{c}227.1 \pm 17.4 \\
(207-250)\end{array}$ & $\begin{array}{l}307.9 \pm 11.8 \\
(291-324)\end{array}$ & 218.5 & $\begin{array}{l}319.5 \pm 42.0 \\
(270-360)\end{array}$ \\
\hline $\begin{array}{l}\text { Width of muscular } \\
\text { esophagus }\end{array}$ & $\begin{array}{l}22.9 \pm 3.0 \\
(21-25)\end{array}$ & $\begin{array}{c}40.2 \pm 10.3 \\
(30-51)\end{array}$ & $\begin{array}{l}27.7 \pm 2.7 \\
(25-31)\end{array}$ & $\begin{array}{c}41.3 \pm 4.41 \\
(36-48)\end{array}$ & 23 & $\begin{array}{l}41.6 \pm 1.9 \\
(39-44)\end{array}$ \\
\hline Length of bulb & $\begin{array}{l}50.3 \pm 0.4 \\
(50-51)\end{array}$ & $\begin{array}{l}82.5 \pm 8.6 \\
(75-92)\end{array}$ & $\begin{array}{l}70.6 \pm 5.4 \\
(67-80)\end{array}$ & $\begin{array}{l}98.8 \pm 7.0 \\
(87-113)\end{array}$ & 57.5 & $\begin{array}{l}91.5 \pm 9.4 \\
(80-103)\end{array}$ \\
\hline Width of bulb & $\begin{array}{l}61.5 \pm 5.6 \\
(57-65)\end{array}$ & $\begin{array}{l}108.2 \pm 10.2 \\
(101-120)\end{array}$ & $\begin{array}{l}68.7 \pm 6.5 \\
(60-78)\end{array}$ & $\begin{array}{l}104.2 \pm 7.6 \\
(97-122)\end{array}$ & 55.2 & $\begin{array}{c}104.3 \pm 11.1 \\
(93-120)\end{array}$ \\
\hline $\begin{array}{l}\text { Nerve ring from } \\
\text { anterior end }\end{array}$ & $\begin{array}{l}162.5 \pm 67.1 \\
(115-210)\end{array}$ & $\begin{array}{l}180.6 \pm 25.7 \\
(162-210)\end{array}$ & $\begin{array}{c}147.0 \pm 10.6 \\
(138-158)\end{array}$ & $\begin{array}{c}211.9 \pm 18.6 \\
(192-252)\end{array}$ & 160 & $\begin{array}{c}269.0 \pm 66.7 \\
(210-360)\end{array}$ \\
\hline $\begin{array}{l}\text { Excretory pore from } \\
\text { anterior end }\end{array}$ & $\begin{array}{c}265,1 \pm 119,0 \\
(182-350)\end{array}$ & $\begin{array}{c}251,6 \pm 42,5 \\
(210-295)\end{array}$ & $\begin{array}{l}217.6 \pm 20.8 \\
(200-252)\end{array}$ & $\begin{array}{l}343.1 \pm 54.7 \\
(276-420)\end{array}$ & 240 & $\begin{array}{c}394.5 \pm 78.4 \\
(300-480)\end{array}$ \\
\hline $\begin{array}{l}\text { Anus from posterior } \\
\text { end }\end{array}$ & $\begin{array}{l}127.5 \pm 17.7 \\
(115-140)\end{array}$ & $\begin{array}{c}480.0 \pm 191.6 \\
(350-700)\end{array}$ & $\begin{array}{l}145.9 \pm 8.0 \\
(135-155)\end{array}$ & $\begin{array}{c}524.5 \pm 139.4 \\
(350-800)\end{array}$ & 151.8 & $\begin{array}{c}453.5 \pm 141.9 \\
(312-650)\end{array}$ \\
\hline Gobernaculum & $\begin{array}{l}112.0 \pm 14.1 \\
(102-122)\end{array}$ & - & $\begin{array}{l}73.8 \pm 9.7 \\
(60-85)\end{array}$ & - & 85 & - \\
\hline Spicules & $\begin{array}{l}111.5 \pm 4.9 \\
(108-115)\end{array}$ & - & $\begin{array}{l}72.6 \pm 4.4 \\
(70-80)\end{array}$ & - & 110 & - \\
\hline $\begin{array}{l}\text { Number of } \\
\text { plectanes }\end{array}$ & 5 pairs & - & $4-5$ pairs & - & 6 pairs & - \\
\hline Adanal papillae & 3 pairs +1 & - & $2-4$ pairs +1 & - & 3 pairs +1 & - \\
\hline $\begin{array}{l}\text { Vulva from anterior } \\
\text { end }\end{array}$ & - & $\begin{array}{l}2.56 \pm 0.96 \mathrm{~mm} \\
\quad(1.7-3.6)\end{array}$ & - & $\begin{array}{c}2.5 \pm 0.51 \mathrm{~mm} \\
(1.95-3.82)\end{array}$ & - & $\begin{array}{c}2.70 \pm 0.34 \mathrm{~mm} \\
(2.29-3.15)\end{array}$ \\
\hline Length of eggs & - & $\begin{array}{l}100.4 \pm 8.1 \\
(92-108)\end{array}$ & - & $\begin{array}{l}110.0 \pm 3.7 \\
(103-116)\end{array}$ & - & $\begin{array}{l}96.6 \pm 6.1 \\
(91-103)\end{array}$ \\
\hline Width of eggs & - & $\begin{array}{c}62.9 \pm 11.3 \\
(55-76)\end{array}$ & - & $\begin{array}{c}71.0 \pm 4.0 \\
(66-78)\end{array}$ & - & $\begin{array}{c}65.7 \pm 6.0 \\
(57-71)\end{array}$ \\
\hline
\end{tabular}


marchesianus, Epipedobates femoralis (Dendrobatidae), Eleutherodactylus imitatrix and Leptodactylus leptodactyloides (Leptodactylidae) by Bursey et al. (2001), in Brazil in Scinax fuscomarginatus (Goldbergetal. 2007), and, in Argentina, in Pseudopaludicola falcipes (Leiuperidae), Leptodactylus bufonius, L. latinasus, L. chaquensis (Leptodactylidae) and Chaunus granulosus major, C. bergi and C. fernandezae (Bufonidae) (González and Hamann 2004, 2006a,b, 2007a, b, Hamann et al. 2006a, b).

Cosmocerca parva was found in Leptodactylus mystaceus, L. caliginosus, L. fuscus, L. ocellatus, Adenomera marmorata, Physalaemus signiferus and $P$. soaresi (Leptodactylidae) and Olylogon fuscovaria (Hylidae) from Brazil (Silva 1954, Fabio 1982); in Leptodactylus sp., L. chaquensis, L. elenae (Leptodactylidae) and Olylogon fuscovaria (Hylidae) from Paraguay (Masi Pallares and Maciel 1974, Baker and Vaucher 1984); in Bufo glaberrimus, B. marinus and $B$. typhonius (Bufonidae), Epipedobates pictus (Dendrobatidae), Hyla fasciata, Phyllomedusa atelopoides, Scarthyla ostinodactyla, Scinax garbei, S. icterica (Hylidae), Edalorhina perezi, Eleutherodactylus fenestratus, E. peruvianus, E. toftae, Leptodactylus leptodactyloides, L. mystaceus (Leptodactylidae), Elachistocleis ovalis and Hamptophryne boliviana (Microhylidae) from Peru (Bursey et al. 2001). Finally, in Argentina, it was found in bufonids Chaunus granulosus major, C. fernandezae and C. bergi and, in leptodactylids Leptodactylus bufonius, L. chaquensis and L. latinasus (Mordeglia and Digiani 1998, González and Hamann 2006a,b, González and Hamann 2007a, b, Hamann et al. 2006a, b).

The general metric characteristics of the specimens of Cosmocerca podicipinus corresponds to others nematodes of the same species analyzed from others hosts of Corrientes, Argentina. Nevertheless, the body size of the females of this study is greater $(3.0-7.0 \mathrm{~mm})$ than the found ones in other hosts; for example, the maximum body size of females of C. podicipinus from P. falcipes: $6.0 \mathrm{~mm}$ (González and Hamann, 2004); from C. fernandezae: $4.3 \mathrm{~mm}$; from $C$. bergi: $6.9 \mathrm{~mm}$ (González and Hamann, 2007a). The other metric characters, in both males and females, are similar to those found by the authors mentioned for this geographic region. The length of spicule of male collected from $S$. acuminatus is longer than found in $R$. schneideri.

With respect to Cosmocerca parva, we found that the female specimens collected from $R$. schneideri are longer than found in S. acuminatus and the other specimens collected from bufonids of the same area, i.e., from Chaunus granulosus major: $5.1 \mathrm{~mm}$ (González and Hamann 2006a); C. fernandezae: $6.7 \mathrm{~mm}$ and C. bergi: $5.6 \mathrm{~mm}$ (González and Hamann 2007a).

The males of C. parva can have from 5 to 7 pairs of plectanes (Baker and Vaucher 1984). In the present study, the most males of C. parva analyzed from $R$. schneideri had 5 pairs of plectanes, although some of them had 4 pairs. Each plectane was formed by one interior complete rosette of 12-15 punctations and one exterior complete rosette of 12-15 punctations, and, a relatively inconspicuous underlying sclerotized support which is not fused to other plectanes. Previously reports of plectanes with scanning electron microscopy realized by Mordeglia and Digiani (1998) showed 12-16 punctations in each rosette of these structures. The only male of C. parva found in S. acuminatus presented 6 pairs of plectanes.

The numbers of pairs of adanal papillae varied between 2 and 4 pairs in specimens from $R$. schneideri but were 3 pairs only in male collected from $S$. acuminatus. González and Hamann (2006a, 2007a) found 2-4 pairs of adanal papillae in males of C. parva from C. granulosus major and $C$. fernandezae; and 3 pairs only in males from $C$. bergi. We observed the unpaired little papilla on the anterior lip of anus in males of C. parva in both hosts of this study.

Both, R. schneideri and S. acuminata, represent new host records for $C$. podicipinus and C. parva. 

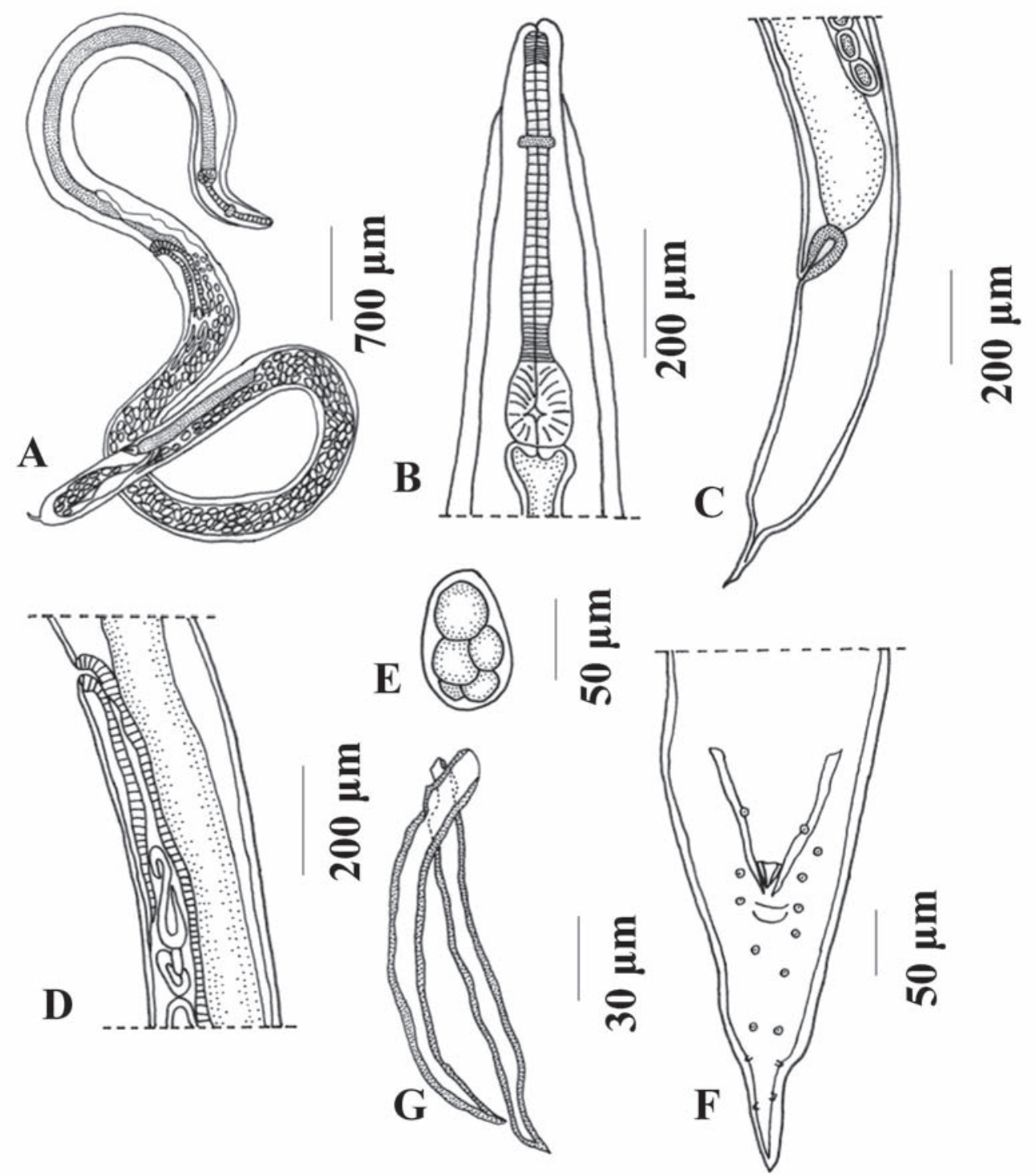

Fig. 2. Nematode parasites of Rhinella schneideri and Scinax acuminatus from Corrientes, Argentina. A. Oxyascaris caudacutus, female, general view. B. body anterior, ventral view. C. body posterior, lateral view. D. detail of vulva, lateral view. E. egg. F. Oxyascaris caudacutus, male, body posterior, ventral view. G. detail of spicules.

Genus Oxyascaris Travassos, 1920

Oxyascaris caudacutus (Freitas, 1958)

Baker \& Vaucher, 1984 (Fig. 2 A-G)

Description: Nematodes with marked dimorphism in size; mature females more than twice as large as male. Oral opening triangular, three small lips present. Four large outer papillae and six minute inner labial papillae in the cephalic extremity. Lateral alae extending from just anterior to nerve ring in both sexes to the preanal region in males and to near midbody in 
females. Markedly wide and thick at anterior end and tapering rapidly posteriorly. Somatic papillae present, in two subventral and two subdorsal rows.

Males: based on 3 specimens. Body $3.4 \pm 0.65 \mathrm{~mm}(2.65-3.9 \mathrm{~mm}) \times 173.33 \pm 32.14$ (150-210). Pharynx 31.5 $\pm 7.46 \quad(23-37) \mathrm{x}$ $22.56 \pm 1.69$ (20.7-24). Esophagus divided in two portions: corpus $290 \pm 28.28$ (270-310) x $29.93 \pm 4.60$ (25.3-34.5), and bulb $72.0 \pm 4.24$ (69-75) x 68.26 \pm 9.61 (57.5-76). Nerve ring $200.0 \pm 70.71$ (150-250) from anterior extremity. Excretory pore $370.6 \pm 25.32$ (342-390) from anterior extremity. Tail conical, 208.0 \pm 9.16 (198-216) long, with four pairs of subventral and two pairs of subdorsal papillae; one umpaired papilla on anterior lip of cloaca, and three pairs of subventral papillae variable in position. Spicules sharply pointed distally, $144.0 \pm 29.4$ (110-161) long. Gubernaculm weakly sclerotized, 37.25 \pm 3.88 (34.5-40) long.

Females: based on 7 gravid specimens. Body $12.0 \pm 2.07 \mathrm{~mm}(9.0-16.0 \mathrm{~mm}) \mathrm{x}$ $272.0 \pm 58.93$ (165-375) with maximum width at level of vulva. Pharynx 45.91 \pm 6.71 (34.5$57.5) \times 42.04 \pm 5.83$ (34.5-52.9). Esophagus divided in two portions: corpus $439.0 \pm 34.47$ (384-498) x 46.84 \pm 7.91 (34.5-57.5), and bulb $91.15 \pm 9.78(78.2-110) \times 89.03 \pm 8.91$ (75.9100). Nerve ring $415.5 \pm 50.04$ (342-450) from anterior extremity. Excretory pore $434.8 \pm 62.91$ (354-534) from anterior end of body. Vulva $4.0 \pm 0.59$ (3.15-4.8) from anterior extremity. Tail robust, tapering abruptly to distal spike, $0.90 \pm 0.11 \mathrm{~mm}(0.67-1.05 \mathrm{~mm})$ long. Uteri in mature females containing many eggs and free larvae. Eggs oval, thin-walled, $84.48 \pm 10.91$ (69-103.5) x 52.28 \pm 5.75 (46-62.140), often contains fully developed larvae.

Remarks: This species was originally described from Hyla nasica (identification of host not definitive according to Freitas 1958), of Sao Paulo, Brazil. Then, it was found in Leptodactylus fuscus and L. mystacinus (Leptodactylidae) from Brazil, too (Fabio 1982) and, in Ololygon fuscovaria (Hylidae) from Paraguay (Baker and Vaucher 1985). This is the first report of this species for Argentinean amphibians.

The general morphology of this specimens correspond with others descriptions (Freitas 1958, Baker and Vaucher 1985) but we added with this study some metric characters, e.i., the range of body size of male specimens: of these study are greater than of those of the original description, and of the other host (Freitas 1958: 2.78-3.62 mm; Baker and Vaucher 1985: 3.50-3.70 mm; present study: 2.65-3.90 mm); in these specimens they have been spicules of greater length than in the specimens of previous studies (Freitas 1958: 122-134 $\mu \mathrm{m}$; Baker and Vaucher 1985: 148-155 $\mu \mathrm{m}$; present study: $110-161 \mu \mathrm{m})$; finally, with respect to gubernaculum, Freitas (1958) does not provide any measurement of this masculine genital structure; on the other hand, Baker and Vaucher (1985) found in this structure a length between 36 and $40 \mu \mathrm{m}$. The lateral alae got to measure $35 \mu \mathrm{m}$ in specimens studied by Baker and Vaucher (1985), whereas in the present study they reached $39 \mu \mathrm{m}$.

Family Kathlaniidae Lane, 1914

Genus Falcaustra Lane, 1915

Falcaustra mascula (Rudolphi, 1819)

Freitas \& Lent, 1941 (Fig. 3 A-C)

Description: Based on 2 females specimens. Body $10.75 \pm 1.9 \mathrm{~mm}(9.37-12.12 \mathrm{~mm}) \mathrm{x}$ $405 \pm 7.07$ (400-410). Cuticle with fine longitudinal striations. Pharynx 75.0 7.07 (70-80) x $71.0 \pm 1.41$ (70-72). Esophagus (with isthmus) $1.38 \pm 0.017 \mathrm{~mm}(1.37-1.4 \mathrm{~mm}) \times 70.8 \pm 5.86$ (66.7-75); isthmus $135.0 \pm 21.21(120-150) \mathrm{x}$ $105.0 \pm 7.07$ (100-110); bulb $163.5 \pm 2.12$ (162165) x 193.0 99.89 (186-200). Nerve ring $345.0 \pm 7.07$ (340-350) from anterior end of body. Excretory pore $1.09 \pm 0.22 \mathrm{~mm}$ (0.93$1.25 \mathrm{~mm}$ ) from anterior extremity. Vulva $7.70 \pm 1.73 \mathrm{~mm}$ (6.47-8.92) from anterior end of body. Tail $355.0 \pm 7.07$ (350-360) in length. The studied females did not have eggs.

Remarks: In South America, Falcaustra mascula was found in Leptodactylus ocellatus, L. pentadactylus, L. caliginosus, L. 

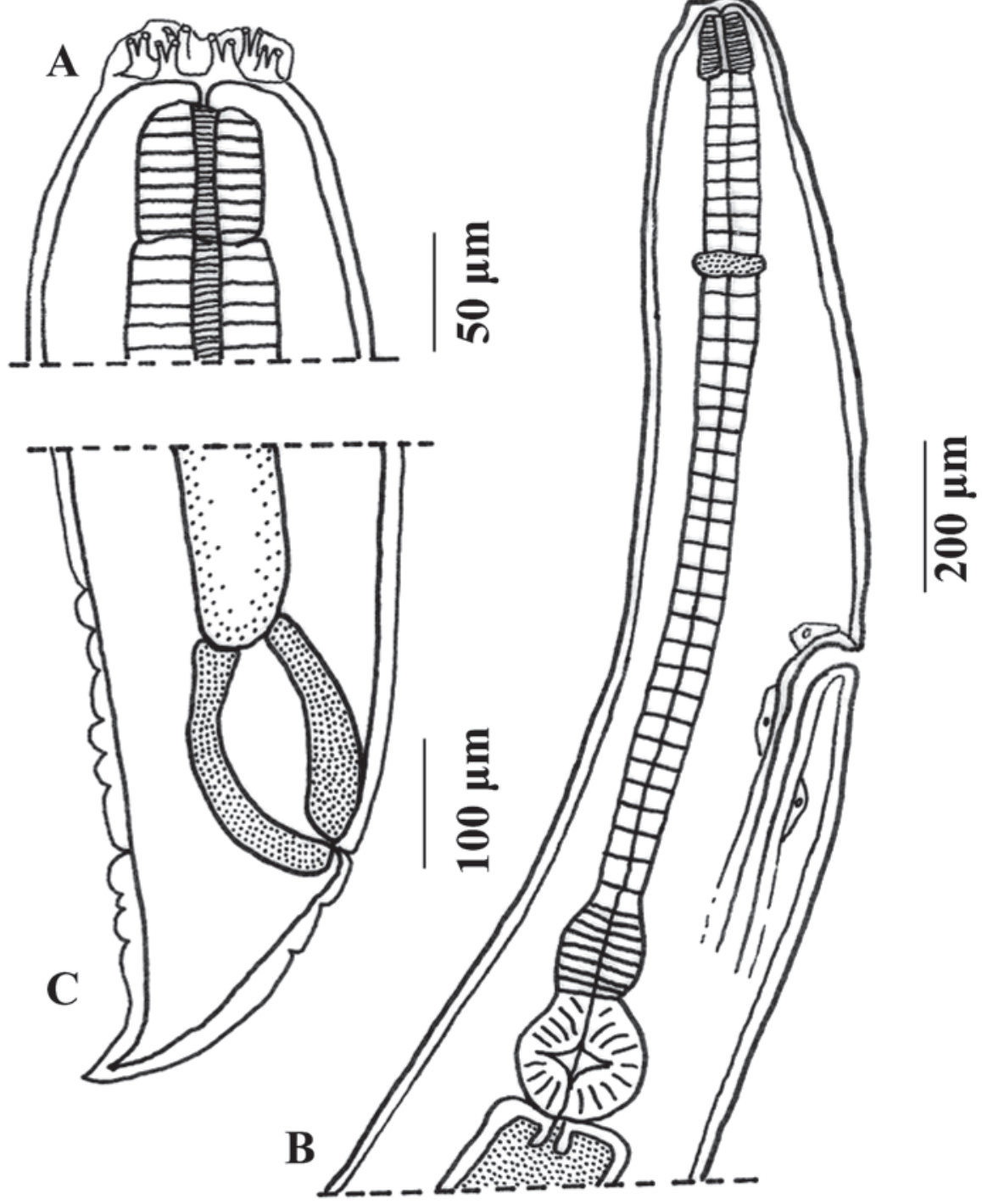

Fig. 3. Nematodes parasites of Rhinella schneideri and Scinax acuminatus from Corrientes, Argentina. A. Falcaustra mascula, female, detail of cephalic end. B. body anterior end, lateral view. C. body posterior end.

rhodomystax, Crossodactylus gaudichaudii, Eleutherodactylus parvus, E. guentheri and Elosia nasus (Leptodactylidae), Bufo paracnemis and B. ictericus (Bufonidae), Hyla faber (Hylidae) from Brazil and Paraguay (Freitas and Lent 1941, Lent et al. 1946, Gomes and Vicente 1966, Vicente and dos Santos 1976, Guimaraes et al. 1976, Fabio 1982, Rodrigues et al. 1982, Baker 1987, Vicente et al. 1990, Luque et al. 2005, Martins and Fabio 2005, Goldberg et al. 2007).

The measurements of these specimens are something greater than those found by Freitas and Lent (1941) and by Vicente and dos Santos (1976); for example, the total length of body (Freitas and Lent 1941: 8.66-9.78 mm; Vicente 
and dos Santos 1976: $7.23 \mathrm{~mm}$; present study: 9.37-12.12 $\mathrm{mm}$ ), the length of excretory pore to anterior end (Freitas and Lent 1941: 1.07-1.20 mm; Vicente and dos Santos 1976: $1.07 \mathrm{~mm}$; present study: $0.93-1.25 \mathrm{~mm}$ ) and the distance of vulva to the anterior end (Vicente and dos Santos 1976: $5.67 \mathrm{~mm}$; present study: 6.47$8.92 \mathrm{~mm}$ ).

This is the first record of $F$. mascula in an amphibian from Argentina.

Family Ascarididae Baird, 1853

Genus Porrocaecum Raillet \& Henry, 1912 Porrocaecum sp. (Larvae)

Description: Based on 1 specimen. Body witish, $9.3 \mathrm{~mm} \times 195.0$. Cuticle almost smooth or with very fine transverse striations. Cephalic end rounded, bearing small ventral larval tooth. Lips with dentigerous ridges. Esophagus narrow, 875.0 long. Nerve ring encircling esophagus, 186.3 from anterior extremity. Excretory pore 222.0 from anterior end of body. Ventriculus elongate 130 x 90; caecum 550 × 37.5. Rectum a short hyaline tube; small rectal glands present. Anus 126.5 from posterior extremity.

Remarks: In South America, Porrocaecum larvae were recorded in Pipa pipa (Pipidae) from Peru (Bursey et al. 2001) and in L. chaquensis (Leptodactylidae) from Argentina (Hamann et al. 2006b). These larvae undoubtedly belong to a Porrocaecum species parasitizing predatory birds, with amphibians and reptiles serving as paratenic hosts.

Family Physalopteridae Leiper, 1908

Genus Physaloptera Rudolphi, 1819 Physaloptera sp. (Larvae)

Description: (corresponding measurements of larvae obtained in $R$. schneideri are given whitin brackets). Larval body whitish, with transversely annulated cuticle. Terminus of head with two lateral lips and cephalic collar formed by inflated cuticle. On either lip a sclerotized support and one terminal tooth present at upper margin. Each lip bearing two cephalic papillae and one amphid. Total length $3.59 \pm 0.65$ $\mathrm{mm} \quad(2.3-4.4)[5.9 \mathrm{~mm}] \times 163.3 \pm 22.7$. (120200) [280.0]. Muscular esophagus $176.0 \pm 18.4$ (138-205) [275.0] x 32.7 $\pm 3.5(28-38)$ [45.0] and glandular esophagus $1.1 \pm 0.13 \mathrm{~mm}(0.8-1.2)$ [1.75mm] x 59.3 $\pm 7.0(51-70)$ [69.0]. Nerve ring and excretory pore from anterior end $149.0 \pm 17.8$ (122-175) [275.0] and 161.1 $12.0(138-174)$ [360.0], respectively. Tail conical. Anus from posterior end 120.7 $\pm 9.4(110-135)$ [120.0].

Remarks: Larvae of this genus were found in the following South American amphibians: Hylafaber(Hylidae), Bufo marinus (Bufonidae), Adenomera marmorata, Leptodactylus caliginosus, L. mystaceus, Physalaemus signiferus, P. soaresi and Proceratophrys appendiculata (Leptodactylidae), from Brazil (BoquimpaniFreitas et al. 2001, Vicente et al. 1990); in Bufo marinus and B. typhonius (Bufonidae), in Colostethus marchesianus (Dendrobatidae), in Hyla boans, H. fasciata, H. granosa, H. leali, H. leucophyllata, H. marmorata, Osteocephalus taurinus, Phrynohyas coriacea, P. venulosa, Phyllomedusa tomopterna, Scinax ictericus and S. ruba (Hylidae), in Edalorhina perezi, Eleutherodactylus cruralis, E. fenestratus, Leptodactylus bolivianus, L. leptodactyloides, L. mystaceus, L. pentadactylus, L. rhodonotus and Lithodytes lineatus (Leptodactylidae), in Ctenophryne geayi and Hamptophryne boliviana (Microhylidae) and Pseudis paradoxa (Pseudidae) from Peru (Bursey et al. 2001). In Argentina, it was found by Gutiérrez et al. (2005) in Physalaemus biligonigerus and by González and Hamann (2006a, b, 2007a) in Leptodactylus bufonius (Leptodactylidae) and in Chaunus granulosus major and in C. fernandezae (Bufonidae). Rhinella schneideri and Scinax acuminatus represent two new records for this nematode.

The measures of the larvae found in the bufonid were, in general, greater than the found ones in the hilids. These measurements 
correspond to the larvae found in other bufonids studied in the same area (González and Hamann 2006a).

\section{DISCUSSION}

Four of nine species of nematodes found in amphibians of this study were new records for Argentina: Rhabdias füelleborni, Oswaldocruzia proencai, Falcaustra mascula and Oxyascaris caudacutus, whereas Rhabdias elegans, Cosmocerca parva, C. podicipinus, Porrocaecum sp. and Physaloptera sp. have previously been reported from Argentinean amphibians. All these nematodes have been found in hylids and bufonids of South America, except Porrocaecum sp. that until now had been found in leptodactilids and pipids amphibians only from Argentina (Hamann et al. 2006b) and Peru (Bursey et al. 2001). In the present study no rhabditids were found in $S$. acuminatus. Besides, this host has less than half species of nematodes that $R$. schneideri.

All nematode species found in this study were classified as generalist because they were not restricted to a single host species.

In general, the bufonids present high predominance of nematodes in their parasitofauna; the highest species richness of nematodes in South America was reported by Luque et al. (2005) in Bufo ictericus from Brazil with thirteen nematodes species. For other bufonids the reports were the following: six species for B. typhonius, four species for B. marinus and Atelopus bomolochus, and two species for $B$. glaberrimus from Peru (Bursey et al. 2001, Iannacone 2003), three species for Atelopus spurelli from Colombia (Goldberg and Bursey 2003), and four species for Chaunus granulosus major and C. fernandezae from Argentina (González and Hamann 2006a, 2007); lowest species richness of nematodes in Argentinean bufonids were two species for $C$. bergi (González and Hamann 2007a,b).

In the genus Scinax nematode species richness is, in general, low. In Peruvian anurans only one species was found in $S$. pedromedinai, two in $S$. garbei and $S$. ruba, and three species in S. icterica (Bursey et al. 2001); in Brazil, Azevedo-Ramos et al. (1998) found two species of nematodes in S. trilineata and in S. nebulosa, and, and Goldberg et al. (2007) found two species in $S$. fuscomarginatus.

In agreement with Bursey et al. (2001), we found different nematode species between R. schneideri (terrestrial habitat), and S. acuminatus (mostly arboreal habitat), suggesting host behaviour and parasites biology are an important factor in the infection of parasites, but, in contraposition of these authors we found the most important intestinal nematodes in terrestrial amphibia were those that infect host by skin penetration (i.e., Rhabdias spp. and Cosmocerca spp.) this result could be explained by the type of habitat in our studies.

\section{ACKNOWLEDGMENTS}

This work was partially supported by Consejo Nacional de Investigaciones Científicas y Técnicas (CONICET) from Argentina, through grant PIP 2945 to M. I. Hamann. The suggestions made by referees have greatly improved the manuscript.

\section{RESUMEN}

Cuarenta y cuatro anfibios pertenecientes a dos especies (Rhinella schneideri-seis machos, tres hembras y dos juveniles- y Scinax acuminatus -quince machos y dieciocho hembras) fueron recolectados para extraer nemátodos en las proximidades de la ciudad de Corrientes, provincia de Corrientes en Argentina, entre enero 2002 y diciembre 2003. Rhinella schneideri estuvo parasitada por ocho especies de nemátodos (adultos: Rhabdias füelleborni, R. elegans, Oswaldocruzia proencai, Cosmocerca podicipinus, C. parva y Falcaustra mascula; larvas: Porrocaecum sp. y Physaloptera sp.), y $S$. acuminatus presentó tres especies de nemátodos (adultos: Cosmocerca parva y Oxyascaris caudacutus; larva: Physaloptera sp.). Para todas estas especies de nemátodos se presentan datos morfológicos y métricos, y para algunas sus nuevos ámbitos y caracteres, así como también los detalles obtenidos mediante el microscopio electrónico de barrido. Éste es el primer informe de nemátodos parásitos para los citados anfibios de Corrientes, Argentina.

Palabras clave: anfibios, Rhinella schneideri, Scinax acuminatus, nemátodos parásitos, Corrientes, Argentina. 


\section{REFERENCES}

Azevedo-Ramos, C., M.M.Q. Santos \& V.R.L Oliveira. 1998. Helminths of Three Amazonian Treefrogs: Interspecific Differences in Prevalence and Infection Intensity of Parasites. Cien. Cult. 50: 361-363.

Baker, M.R. 1987. Synopsis of the nematoda parasitic in amphibians and reptiles. Occasional Papers in Biology. No 11. Memorial University of Newfoundland. Guelph, Ontario, Canada.

Baker, M.R. \& C. Vaucher. 1984. Parasitic Helminths from Paraguay VI: Cosmocerca Diesing, 1861 (Nematoda: Cosmocercoidea) from frogs. Rev. suisse Zool. 91, 925-934.

Baker, M.R. \& C. Vaucher. 1985. Parasitic Helminths from Paraguay VII: Systematic Position of Oxyascaris Travassos, 1920 (Nematoda: Cosmocercoidea). Rev. suisse Zool. 92: 303-310.

Ben Slimane, B. \& M-C. Durette-Desset. 1995. Oswaldocruzia (Nematoda, Trichostrongylina, Molineoidea) parasites d'Amphibiens du Brésil et de l'Équateur, avec redéfinition de l'espèce-type O. subauricularis (Rudolphi, 1819) et d'O. mazzai Travassos, 1935. Rev. suisse Zool. 102: 635-653.

Ben Slimane, B., A.G. Chabaud \& M-C. Durette-Desset. 1996. Les nématodes Trichostrongylinae parasites d'amphibiens et de reptiles: Problèmes toxonomiques, phylétiques et biogéographiques. Syst. Parasitol. 35: 179-206.

Bolek, M.G. \& J.R. Coggins. 2000. Seasonal occurrence and community structure of helminth parasites from the eastern American toad, Bufo americanus americanus from southeastern Wisconsin, U.S.A. Comp. Parasitol. 67: 202-209.

Bolek, M.G. \& J.R. Coggins. 2003. Helminth community structure of sympatric eastern american toad, Bufo americanus americanus, northern leopard frog, Rana pipiens, and blue-spotted salamander, Ambystoma laterale, from southeastern Wisconsin. J. Parasitol. 89: 673-680.

Boquimpani-Freitas, L., D. Vrcibradic, J.J. Vicente, C.R Bursey, C.F.D. Rocha \& M. Van Sluys. 2001. Helminths of the horned leaf frog, Proceratophrys appendiculata, from southeastern Brazil. J. Helminthol. 75: 233-236.

Bursey, C.R., S.R Goldberg \& J.R Pamarlee. 2001. Gastrointestinal helminths of 51 species of anurans from Reserva Cuzco Amazónico, Peru. Comp. Parasitol. 68: 21-35.

Bursey, C.R., S.R Goldberg \& S.R. Telford, Jr. 2003. Rhabdias anolis n. sp. (Nematoda: Rhabdiasidae) from the lizard, Anolis frenatus (Sauria: Polychrotidae), from Panama. J. Parasitol. 89: 113-117.

Bush, A.O., K.D. Lafferty, J.M. Lotz \& A.W. Shostak. 1997. Parasitology meets ecology on its own terms: Margolis et al. revisted. J. Parasitol. 83: 575-583.

Duré, M.I. 2004. Estructura trófica y aspectos ecológicos de los gremios de una comunidad de anfibios de la provincia de Corrientes. Tesis, Universidad Nacional de La Plata. Argentina.

Fabio, S.P. 1982. Helmintos de populações simpátricas de algumas especies de anfibios anuros da familia Leptodactylidae. Arq. Univ. Fed. Rur. Rio de Janeiro 5: 69-83.

Fahel, J. 1952. Fauna helminthologica das "gias" de Salvador (Leptodactylus pentadactylus (Lau.). An. Acad. Brasil. Ci. 24: 389-436.

Freitas, J.F.T. 1958. Estudos sobre "Oxyascarididae" (Travassos, 1920) (Nematoda, Subuluroidea). Mem. Inst.Oswaldo Cruz 56: 489-515.

Freitas J.F.T. \& H. Lent. 1941. Contribução ao estudo da sub-família Kathlaniinae Lane, 1914 (Nematoda, Subuluroidea). Arq. Zool. S. Paulo 3: 13-42.

Gomes, D.C. \& J.J. Vicente. 1966. Ocorrência de Falcaustra mascula (Rud., 1819) em Crossodactylus gaudichaudii Dum. \& Bibr. (Nematoda, Kathlanidae). Atas Soc. Biol. Rio de Janeiro 10: 113-116.

Goldberg, S.R. \& C.R. Bursey. 2003. Helminths of two anuran species; Atelopus spurrelli (Bufonidae) and Dendrobates histrionicus (Dendrobatidae), from Colombia, South America. Parasitol. Int. 52: 251-253.

Goldberg, S.R., C.R. Bursey, J.P. Caldwell, L.J. Vitt \& G.C. Costa. 2007. Gastrointestinal helminths from six species of frogs and three species of lizards, sympatric in Pará State, Brazil. Comp. Parasitol. 74: 327-342.

González, C.E. \& M.I. Hamann. 2004. Primer registro de Cosmocerca podicipinus Baker y Vaucher, 1984 (Nematoda: Cosmocercidae) en Pseudopaludicola falcipes (Hensel, 1867) (Amphibia: Leptodactylidae) en Corrientes, Argentina. Facena 20: 65-72.

González, C.E. \& M.I. Hamann. 2005. Gyrinicola chabaudi Araujo \& Artigas, 1982 (Nematoda: 
Pharyngodonidae) in tadpoles of Scinax nasicus (Cope, 1862) (Anura: Hylidae) from Corrientes, Argentina. Facena 21: 145-148.

González, C.E. \& M.I. Hamann. 2006a. Nematodes parásitos de Chaunus granulosus major (Müller \& Hellmich, 1936) (Anura: Bufonidae) en Corrientes, Argentina. Cuad. Herpetol. 20: 43-49.

González, C.E. \& M.I. Hamann. 2006b. Helmintos parásitos de Leptodactylus bufonius Boulenger, 1894 (Anura: Leptodactylidae) de Corrientes, Argentina. Rev. Esp. Herpetol. 20: 39-46.

González, C.E. \& M.I. Hamann. 2007a. Nematode parasites of two species of Chaunus (Anura: Bufonidae) from Corrientes, Argentina. Zootaxa 1393: 27-34.

González, C.E. \& M.I. Hamann. 2007b. Chaunus bergi (NCN) Endoparasites. Herpetol. Rev. 38: 181.

González, C.E. \& M.I. Hamann. 2007c. The first record of amphibians as paratenic host of Serpinema larvae (Nematoda: Camallanidae). Braz. J. Biol. 67: 579580 .

Guimaraes, J.F., R. Cristofaro \& H.O. Rodrigues. 1976. Alguns nematódeos de anfibios de Salvador, Bahia. Atas Soc. Biol. Rio de Janeiro 18: 71-74.

Gutierrez, R.O. 1945. Contribución al conocimiento de los nematodes parásitos de anfibios argentinos. Tesis. Universidad Nacional de La Plata. Argentina.

Gutierrez, C., A. Attademo, S. Guerrero, P. Peltzer \& R. Lajmanovich. 2005. Physalaemus biligonigerus (False-eyed Frog). Endoparasites. Herpetol. Rev. 36: 161-162.

Hamann, M.I., C.E. González \& A.I. Kehr. 2006a. Helminth community structure of the oven frog Leptodactylus latinasus (Anura, Leptodactylidae) from Corrientes, Argentina. Acta Parasitol. 51: 294-299.

Hamann, M.I., A.I. Kehr \& C.E. González. 2006b. Species affinity and infracommunity ordination of helminths of Leptodactylus chaquensis (Anura: Leptodactylidae) of two contrasting environments from northeastern Argentina. J. Parasitol. 92: 1171-1179.

Ianaconne, J. 2003. Helmintos parásitos de Atelopus bomolochus Peters, 1973 (Anura: Bufonidae) from Piura, Peru. Gayana 67: 9-15.

Kloss, G.R. 1971. Alguns Rhabdias (Nematoda) de Bufo no Brasil. Pap. Avuls. Dep. Zool. S. Paulo 24: 1-52.
Kloss, G.R. 1974. Rhabdias (Nematoda, Rhabditoidea) from the marinus group of Bufo. A study of sibling species. Arq. Zool. 25: 61-120.

Lavilla, E.O., E. Richard \& G.J. Scrocchi. 2000. Categorización de los anfibios y reptiles de la República Argentina. Asociación Herpetológica Argentina. Tucumán, Tucumán. Argentina.

Lent, H., J.F.T. Freitas \& M.C. Proença. 1946. Alguns helmintos de batráquios colecionados no Paraguai. Mem. Inst. Oswaldo Cruz 44: 195-214.

Luque, J.L., A.N. Martins \& L.E.R. Tavares. 2005. Community structure of metazoan parasites of the yellow Cururu toad, Bufo ictericus (Anura, Bufonidae) from Rio de Janeiro, Brazil. Acta Parasitol. 50: 215-220.

Masi Pallares, R. \& S. Maciel. 1974. Helminthes en batracios del Paraguay (1ra. Parte), con descripción de una nueva especie, Aplectana pudenda (Oxyuridae: Cosmocercinae). Rev. Paraguaya Microbiol. 9: 55-60.

Martínez-Salazar, E.A. \& V. León-Règagnon. 2006. Rhabdias lamothei n. sp. (Nematoda: Rhabdiasidae) from Leptodeira maculata (Colubridae) in Mexico, including new records of $R$. fuscovenosa (Railliet, 1899) Goodey, 1924. Zootaxa 1257: 27-48.

Martins,A.N.\& S.P.Fabio. 2005.Parasitismo pornematóides em populações simpátricas de Eleutherodactylus parvus (Girard, 1853) e Eleutherodactylus guentheri (Steindachner, 1864) - (Anura: Leptodactylidae). Acta Biol Leopol. 27: 47-50.

Mordeglia, C. \& M.C. Digiani. 1998. Cosmocerca parva Travassos, 1925 (Nematoda: Cosmocercidae) in Toads from Argentina. Mem. Inst. Oswaldo Cruz 93: 737-738.

Rodrigues, H.O., S.S. Rodrigues \& R. Cristofaro. 1982. Contribução ao conhecimento da fauna helmintológica de Barra do Piraí, Estado do Rio de Janeiro. Atas Soc. Biol. Rio de Janeiro 23: 5-8.

Sueldo, C. \& V.G. Ramírez. 1976. Aportes sobre parásitos de Bufo arenarum en la provincia de Salta (Nematoda). Neotropica 22: 105-106.

Travassos, L. 1926. Entwicklung des Rhabdias füelleborni n. sp. Arch. f Schiffs Trop. Hyg. 30: 594-602.

Vicente, J.J. \& E. dos Santos. 1976. Fauna helmintológica de Leptodactylus ocellatus (L., 1758) de Volta 
Redonda, Estado do Rio de Janeiro. Atas Soc. Biol. Rio de Janeiro 18: 27-42.

Vicente, J.J., H.O. Rodrigues, D.C. Gomes \& R.M. Pinto. 1990. Nematóides do Brasil. Parte II: Nematóides de anfíbios. Rev. Brasil. Zool. 7: 549-626.

Yoder, H.R. \& J.R. Coggins. 1996. Helminth communities in the northern spring peeper, Pseudacris c. crucifer Wied., and the wood frog, Rana sylvatica Le Conte from southeastern Wisconsin. J. Helminthol. Soc. Wash. 63: 211-214.
Yoder, H.R. \& J.R. Coggins. 2007. Helminth communities in five species of sympatric amphibians from three adjacent ephemeral ponds in Southeastern Wisconsin. J. Parasitol. 93: 755-760.

\section{INTERNET REFERENCE}

Frost, D.R. 2007. Amphibian species of the world: an online reference. Version 4.0. American Museum of Natural History, New York, USA. (Downloaded: 19 June 2008, http://research.amnh.org/herpetology/ amphibia/index.php.). 
